CZASOPISMO INŻYNIERII LĄDOWEJ, ŚRODOWISKA I ARCHITEKTURY JOURNAL OF CIVIL ENGINEERING, ENVIRONMENT AND ARCHITECTURE JCEEA, t. XXXIII, z. 63 (3/16), lipiec-wrzesień 2016, s. 75-84

\author{
Jolanta FIEDUCIK ${ }^{1}$
}

\title{
SAMOWYSTARCZALNE ENERGETYCZNIE GOSPODARSTWO AGROTURYSTYCZNE
}

\begin{abstract}
W artykule przedstawiono analizę zaspokojenia potrzeb energetycznych dla energooszczędnego gospodarstwa agroturystycznego. W analizie uwzględniono zapotrzebowanie na energię cieplną do celów grzewczych w ciągu całego roku, ciepłą wodę użytkową oraz energię elektryczną. Analiza oparta jest o energię wytworzoną w gospodarstwie agroturystycznym zapewniającą samowystarczalność pod względem energetycznym. Obliczono zapotrzebowanie w energię grzewczą na podstawie stopniodni w poszczególnych miesiącach roku przyjmując za parametr zużycie energii $40 \mathrm{kWh} / \mathrm{m}^{2} /$ rok. W celu pozyskania energii do ogrzewania gospodarstwa zaproponowano uprawę wierzby energetycznej na własny użytek na odpowiednim areale, a dla ogrzania ciepłej wody użytkowej c.w.u. zaproponowano słoneczne kolektory powietrzne, które oprócz ogrzewania c.w.u. mogą wspomagać ogrzewanie budynku. Analizę zapotrzebowania ciepła na ogrzewanie budynku energooszczędnego przez kolektory powietrzne przeprowadzono przy pomocy programu GetSolar, który służy do symulacji instalacji kolektorów słonecznych w różnych warunkach klimatycznych. Rozważania przeprowadzono dla warunków klimatycznych miasta Olsztyna, uwzględniając napromieniowanie w warunkach północnej Polski. Przedstawiono bilans energii uwzględniając wartość energii napromieniowania słonecznego dla kolejnych miesięcy w roku oraz energii potrzebnej na ogrzanie energooszczędnego domu jednorodzinnego i c.w.u. Do rozważań wykorzystano komercyjne zestawy słonecznych kolektorów powietrznych SolarVenti Hybryd. Na podstawie analizy wyników stwierdzono, że przy zastosowaniu odpowiedniej powierzchni słonecznych kolektorów powietrznych w warunkach północnej Polski, jest możliwe ogrzanie budynku i zaspokojenia potrzeb na ciepłą wodę dla mieszkańców poza miesiącami zimowymi. W tym okresie należy zastosować alternatywne źródła ogrzewania. Przeanalizowano wytworzenie energii elektrycznej na potrzeby gospodarstwa przy wykorzystaniu ogniw fotowoltaicznych. Z przeprowadzonej analizy wynika, że możliwe jest stworzenie samowystarczalnego energetycznie gospodarstwa agroturystycznego w warunkach klimatycznych Olsztyna.
\end{abstract}

Słowa kluczowe: samowystarczalne energetycznie gospodarstwo, wierzba energetyczna, ogniwa fotowoltaiczne, słoneczne kolektory powietrzne

\footnotetext{
${ }^{1}$ Jolanta Fieducik, Uniwersytet Warmińsko-Mazurski w Olsztynie, Wydział Nauk Technicznych, Katedra Elektrotechniki, Energetyki, Elektroniki i Automatyki. Oczapowskiego 11, 10-900 Olsztyn; tel. 512 205 527; jolanta.fieducik@uwm.edu.pl
} 


\section{Wprowadzenie}

Celem artykułu jest przedstawienie możliwości zapewnienia samowystarczalności energetycznej gospodarstwa agroturystycznego na bazie odnawialnych źródeł energii. Koszty ogrzewania gospodarstwa agroturystycznego wraz z podgrzewaniem ciepłej wody użytkowej stanowią przeciętnie od 70 do $80 \%$ rocznych kosztów eksploatacji budynku. Tak więc od zastosowanego rozwiązania grzewczego zależeć będzie większość stałych wydatków ponoszonych na utrzymanie domu. Koszty ogrzewania domu zależą od wielu czynników, w pierwszym rzędzie od jego wielkości i standardu izolacyjności cieplnej, a następnie od rodzaju paliwa i sprawności systemu grzewczego. W zależności od wyboru paliwa czy nośnika energii, można porównać z dużym przybliżeniem koszty wytworzenia $1 \mathrm{kWh}$ ciepła i tym samym ogrzewania budynku.

\subsection{Definicja gospodarstwa agroturystycznego}

Pod pojęciem gospodarstwa agroturystycznego rozumiemy różne formy wypoczynku organizowanego na terenach wiejskich o charakterze rolniczym, przez rodzinę rolniczą bezpośrednio we własnym gospodarstwie wiejskim (rolniczym, rybackim czy ogrodniczym), oparte o bazę noclegową i aktywności rekreacyjne związane $\mathrm{z}$ gospodarstwem rolnym lub równoważnym i jego otoczeniem przyrodniczym, produkcyjnym i usługowym.

Ofertą agroturystyczną jest zakwaterowanie w gospodarstwie, które może być połączone z całodziennym wyżywieniem lub możliwością zakupu świeżych produktów z gospodarstwa do samodzielnego przyrządzania posiłków. Prowadzić je może tylko rolnik mający powyżej 1ha gruntów, ubezpieczony w Kasie Rolniczego Ubezpieczenia Społecznego KRUS, wynajmować może 5 pokoi w domu na wsi wspólnie zamieszkałym z wczasowiczami bez konieczności zgłaszania działalności gospodarczej. Ma to spowodować:

- możliwości uzyskania dodatkowych dochodów dla rolników;

- poprawę życia na wsi;

- stworzenie dla mieszkańców miast korzystnych warunków wypoczynku przez bezpośredni dostęp do naturalnych warunków środowiska, w kameralnych warunkach.

\subsection{Założone parametry energooszczędnego gospodarstwa agroturystycznego}

Aby zapewnić niezbędną energię do ogrzewania dla domu energooszczędnego w standardzie NF 40 (Narodowy Fundusz) potrzebne jest $40 \mathrm{kWh} / \mathrm{m}^{2} \cdot$ rok $[1,2]$. Do analizy w artykule założono:

- budynek o podstawie: $10 \mathrm{~m} \times 10 \mathrm{~m}$;

- powierzchnia użytkowa: $150 \mathrm{~m}^{2}$;

- dach dwuspadowy o kącie nachylenia: $45^{\circ}$;

- powierzchnia dachu od strony południowej: $70 \mathrm{~m}^{2}$;

- dom w warunkach klimatycznych Olsztyna, (IV strefa klimatyczna); 
- zużycie ciepłej wody na 10 osób wg normy;

- zastosowanie wentylacji mechanicznej z odzyskiem ciepła - rekuperacja;

- możliwość wykorzystywania ciepła $z$ energii słonecznej (montaż instalacji kolektorów).

\section{Propozycja ogrzewania gospodarstwa agroturystycznego przy wykorzystaniu zrębków wierzby energetycznej}

$\mathrm{Na}$ ogrzewanie gospodarstwa domowego na wsi wg danych Głównego Urzędu Statystycznego GUS [3] w 2015 roku wykorzystywano drewno opałowe $-89 \%$, inne paliwa z biomasy $-8 \%$, pozostałe paliwa kopalniane $-3 \%$.

Struktura urządzeń do ogrzewania pomieszczeń była następująca:

- kotły dwufunkcyjne 50,9\%;

- kotły jednofunkcyjne 33,5\%;

- piece i kominki 16,2\%.

\subsection{Zapotrzebowanie na energię do ogrzania budynku gospodarstwa agroturystycznego i c.w.u.}

$\mathrm{Na}$ ogrzanie w ciągu roku domu energooszczędnego wg standardu NF 40 o powierzchni $150 \mathrm{~m}^{2}$ potrzebna jest energia $6000 \mathrm{kWh}$ $\left(150 \mathrm{~m}^{2} \times 40 \mathrm{kWh} / \mathrm{m}^{2} \cdot\right.$ rok $)$. Zapotrzebowanie na energię do ogrzewania budynku i na przygotowanie ciepłej wody użytkowej c.w.u. dla 10 osób w poszczególnych miesiącach przedstawiono poniżej w tabeli 1 [4].

Jak wynika $z$ analizy danych w tabeli 1 , energia $Q$ o na ogrzewanie domu i energia $Q$ cwu na przygotowanie c.w.u. daje w sumie łączną energię około $E \mathrm{c}=16160 \mathrm{kWh}$ w ciągu roku. Przy wykorzystaniu kotła dwufunkcyjnego i przy średniej sprawności $\eta=80 \%$, zapotrzebowanie roczne $Q$ na energię z biomasy wynosi:

$$
\begin{aligned}
& Q=E c / \eta, \\
& Q=16160 \mathrm{kWh} / 0,80=20200 \mathrm{kWh} .
\end{aligned}
$$

Przeliczając $\mathrm{kWh}$ na $\mathrm{MJ}$, gdzie $1 \mathrm{kWh}=3,6 \mathrm{MJ}$ otrzymujemy zapotrzebowanie roczne $\mathrm{w} \mathrm{MJ}$ :

$$
Q=20200 \mathrm{kWh} * 3,6 \mathrm{MJ} / \mathrm{kWh}=72720 \mathrm{MJ} \text {. }
$$

Zakładając, że wartość energetyczna We zrębków z wierzby energetycznej przy zawartości $20 \%$ wilgoci wynosi $W \mathrm{e}=12000 \mathrm{MJ} / \mathrm{Mg}$, to $\mathrm{Mz}$ masa rocznego zapotrzebowania na zrębki wyniesie [5]:

$$
\begin{aligned}
& M z=\mathrm{Q} / \mathrm{We}, \\
& M z=72720 \mathrm{MJ} / 12000 \mathrm{MJ} / \mathrm{Mg}=6,06 \mathrm{Mg}
\end{aligned}
$$


Zatem do ogrzania gospodarstwa agroturystycznego i na przygotowanie c.w.u. dla średnio10 osób potrzeba teoretycznie około $6 \mathrm{Mg}$ zrębków wierzby energetycznej, które uzyskać można z 0,5 hektara plantacji [5]. Co prawda 0,5 ha uprawy wystarczy na jeden rok ogrzewania, ale wierzba energetyczna w praktyce zbierana jest w cyklu 3 letnim, dlatego areał uprawy powinien wynosić 1,5 ha. Przy tym rozwiązaniu uwzględniono niezbędny okres suszenia wierzby. W gospodarstwie agroturystycznym kocioł centralnego ogrzewania może być używany na inną biomasę, np. drewno, brykiety, pelety, trociny, natomiast popiół ze spalania biomasy można używać jako nawóz.

Tabela 1. Zapotrzebowanie roczne na energię do ogrzewania i przygotowania c.w.u.

Table 1. Annual demand for energy for heating and hot tap water

\begin{tabular}{|c|c|c|}
\hline Miesiąc & $\begin{array}{l}\text { Energia potrzebna na } \\
\text { ogrzewanie domu } 150 \mathrm{~m}^{2} \\
\text { standard NF } 40\end{array}$ & Energia na c.w.u. dla 10 osób \\
\hline & [kWh] & [kWh] \\
\hline 1 & 1310 & 862 \\
\hline$\|$ & 886 & 779 \\
\hline III & 700 & 862 \\
\hline IV & 379 & 836 \\
\hline V & 184 & 862 \\
\hline $\mathrm{VI}$ & 45 & 836 \\
\hline VII & 0 & 862 \\
\hline VIII & 13 & 862 \\
\hline IX & 160 & 836 \\
\hline$x$ & 532 & 862 \\
\hline XI & 575 & 836 \\
\hline XII & 1217 & 862 \\
\hline Razem & 6001 & 10157 \\
\hline
\end{tabular}

\section{Analiza ogrzewania budynku i ciepłej wody użytkowej w gospodarstwie agroturystycznym przy wykorzystaniu powietrznych kolektorów słonecznych}

Budowę i zasadę działania kolektora słonecznego przedstawiono na rysun$\mathrm{ku} 1$. Powietrze $\mathrm{z}$ zewnątrz przez tylną perforowaną ściankę zasysane jest do wnętrza kolektora, gdzie ogrzewa się. Ogrzane powietrze przez wentylator kie- 
rowane jest do wnętrza ogrzewanego pomieszczenia [6]. Wentylator zasilany jest energią elektryczną uzyskiwaną z modułu fotowoltaicznego wbudowanego w kolektor. Kolektory powietrzne można montować pionowo lub poziomo na południowej stronie budynku. Szczególną uwagę należy zwrócić na drzewa, budynki czy inne wysokie przedmioty, które w okresie zimowym, gdy Słońce jest zbyt nisko, mogą rzucać cień na kolektor. Kolektor słoneczny można montować bezpośrednio na ścianie, słupkach drewnianych tuż obok budynku lub stelażu przeznaczonym do montażu na dachu. Ogrzane powietrze przekazywane zostaje do budynku za pomocą kanału elastycznego, łączącego kolektor z anemostatem nawiewnym w pomieszczeniu.

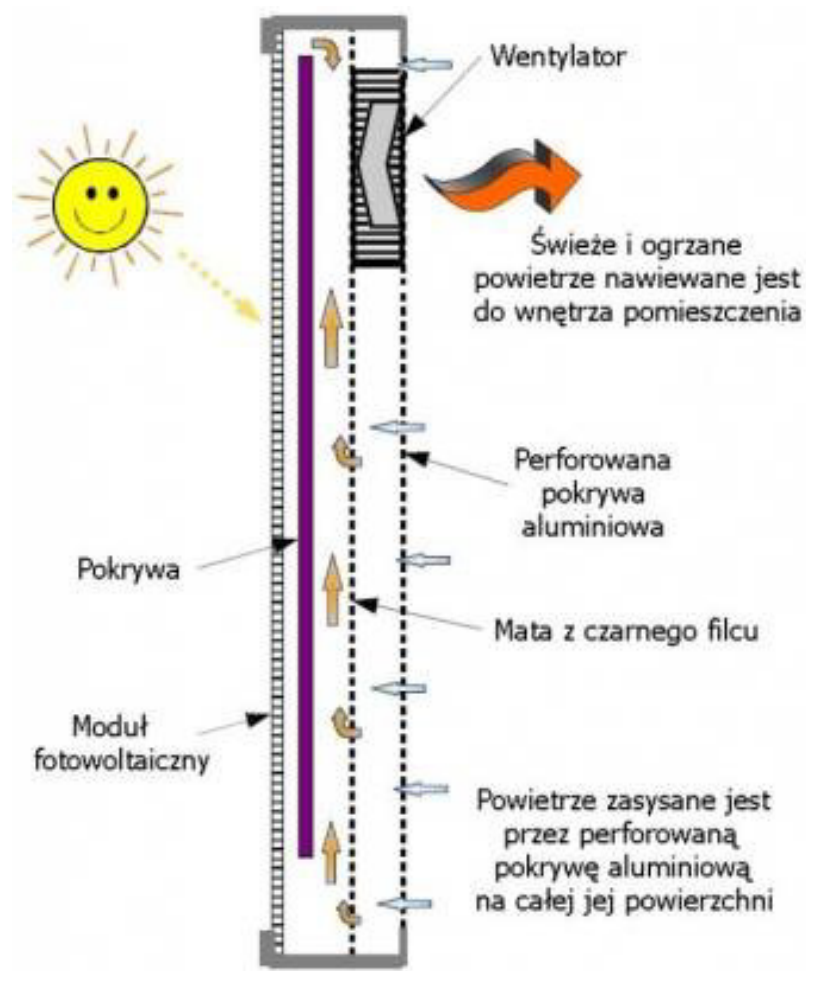

Rys.1. Schemat kolektora powietrznego [6]

Fig. 1. Diagram of the air collector [6]

Powietrzne kolektory słoneczne połączone $\mathrm{z}$ wymiennikiem ciepła można wykorzystać w gospodarstwie agroturystycznym do ogrzewania budynków i do przygotowania ciepłej wody użytkowej.

Schemat takiej instalacji i zasadę działania przedstawiono na rysunku 2. 
Tryb Ogrzewanie/ Wentylacia
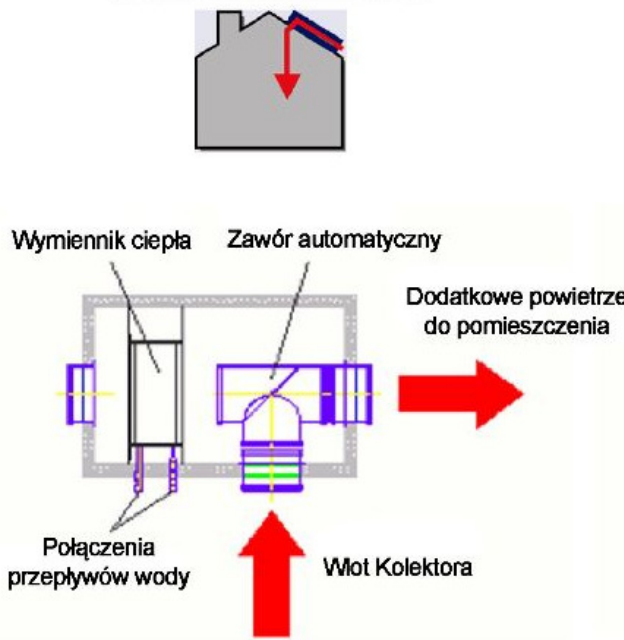

Tryb Goracej Wody
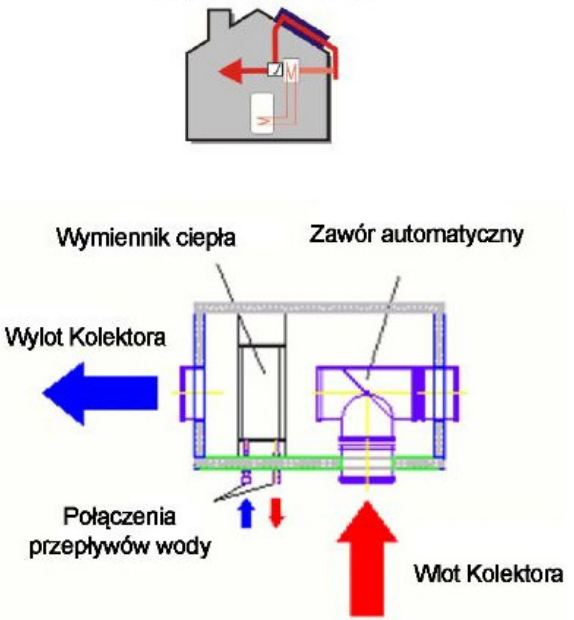

Rys.2. Schemat instalacji kolektora powietrznego z wymiennikiem ciepła [7]

Fig. 2. Installation diagram collector air heat exchanger [7]

Przy trybie pracy ogrzewanie /wentylacja ogrzane w kolektorze powietrze poprzez zawór automatyczny kierowane jest do pomieszczeń budynku. W trybie pracy gorącej wody powietrze z kolektora poprzez zawór automatyczny kierowane jest do wymiennika ciepła podgrzewając wodę.

$\mathrm{W}$ tabeli 2 przedstawiono dane $\mathrm{w}$ skali roku $\mathrm{z}$ napromieniowania i bilans energii dla instalacji powietrznych kolektorów słonecznych o powierzchni $60 \mathrm{~m}^{2}$ wykorzystanej do ogrzewania budynku w standardzie NF 40 i powierzchni $150 \mathrm{~m}^{2}$ oraz ciepłej wody użytkowej dla 10 osób.

$\mathrm{Z}$ napromieniowania $1 \mathrm{~m}^{2}$ słonecznego kolektora powietrznego w ciągu roku można uzyskać średnią energię napromieniowania $E n=1092 \mathrm{kWh} / \mathrm{m}^{2}$. Dla instalacji kolektorów o powierzchni $S k=60 \mathrm{~m}^{2}$ i sprawności kolektorów $\eta k=70 \%$ w ciągu roku możemy uzyskać energię całkowitą $Q c$ na ogrzewanie i ciepłą wodę użytkową [8]:

$$
\begin{aligned}
& Q \mathrm{c}=E n * S k * \eta k, \\
& Q c=1092 \mathrm{kWh} / \mathrm{m}^{2} * 60 \mathrm{~m}^{2} * 70 \%=45868 \mathrm{kWh} .
\end{aligned}
$$

Jeżeli wartość energii całkowitej $Q c$ pomniejszymy o energię $Q o g r z=6000 \mathrm{kWh}$ na ogrzewanie domu i $Q c w u=10169 \mathrm{kWh}$ na ogrzewanie c.w.u. to w skali roku otrzymamy nadwyżkę energii z kolektorów $Q$ n:

$$
Q n=Q c-Q o g r z-Q c w u,
$$




$$
Q n=45868-6000-10169=29699[\mathrm{kWh}],
$$

gdzie Qn - nadwyżka energii cieplnej ze słonecznych kolektorów powietrznych.

Tabela 2. Bilans energii z kolektorów do ogrzewania i przygotowanie c.w.u. w roku [8,9]

Table 2. Balance energy collectors for heating and preparing hot tap water in year $[8,9]$

\begin{tabular}{|c|c|c|c|c|c|c|}
\hline Miesiąc & \begin{tabular}{|c|} 
Napromie \\
niowanie \\
na $1 \mathrm{~m}^{2}$ \\
kolektora
\end{tabular} & \begin{tabular}{|c|} 
Napromieniowanie \\
całkowite kolektora \\
powietrznego o \\
pow. $60 \mathrm{~m}^{2}$
\end{tabular} & \begin{tabular}{|c|} 
Energia \\
potrzebna na \\
ogrzewanie \\
domu $150 \mathrm{~m}^{2}$ \\
standard NF \\
40
\end{tabular} & $\begin{array}{l}\text { Energia na } \\
\text { c.w.u. }\end{array}$ & \begin{tabular}{|c|} 
Zysk \\
solarny z \\
kolektora \\
$60 \mathrm{~m}^{2}$ - \\
sprawność \\
$70 \%$
\end{tabular} & \begin{tabular}{|c} 
Nadmiar energii \\
na ogrzewanie \\
$(+)$ lub niedomiar \\
(-) energii przy \\
kolektorze o \\
pow. $60 \mathrm{~m} 2$
\end{tabular} \\
\hline & kWh & kWh & kWh & kWh & kWh & kWh \\
\hline I & 24,4 & 1464 & 1310 & 863 & 1025 & -1148 \\
\hline II & 37,2 & 2232 & 886 & 780 & 1562 & -104 \\
\hline III & 77,9 & 4674 & 700 & 863 & 3272 & 1709 \\
\hline IV & 119 & 7140 & 379 & 837 & 4998 & 3782 \\
\hline $\mathrm{V}$ & 152 & 9120 & 184 & 863 & 6384 & 5337 \\
\hline $\mathrm{VI}$ & 165 & 9900 & 45 & 837 & 6930 & 6048 \\
\hline VII & 168 & 10080 & 0 & 863 & 7056 & 6193 \\
\hline VIII & 144 & 8640 & 13 & 863 & 6048 & 5172 \\
\hline IX & 100 & 6000 & 160 & 837 & 4200 & 3203 \\
\hline$x$ & 61,6 & 3696 & 532 & 863 & 2587 & 1192 \\
\hline$X I$ & 25,6 & 1536 & 575 & 837 & 1075 & -337 \\
\hline XII & 17,4 & 1044 & 1217 & 863 & 731 & -1349 \\
\hline Razem & 1092 & 65520 & 6000 & 10169 & 45868 & 29699 \\
\hline
\end{tabular}

Analizując bilans uzyskiwanej z kolektorów nadwyżki wynika, że jej wartość jest największa w miesiącach letnich. W miesiącach listopad, grudzień, styczeń i luty energia z kolektorów nie pokrywa w pełni zapotrzebowania na ogrzewanie budynku oraz ciepłej wody użytkowej i niezbędne jest dodatkowe źródło ciepła do wyrównania bilansu. Możliwe jest również budowa instalacji do magazynowania energii cieplnej z miesięcy o dużej nadwyżce i wykorzystania jej w okresie niedoboru.

Poniżej dane z tabeli zobrazowano na rys.3. 


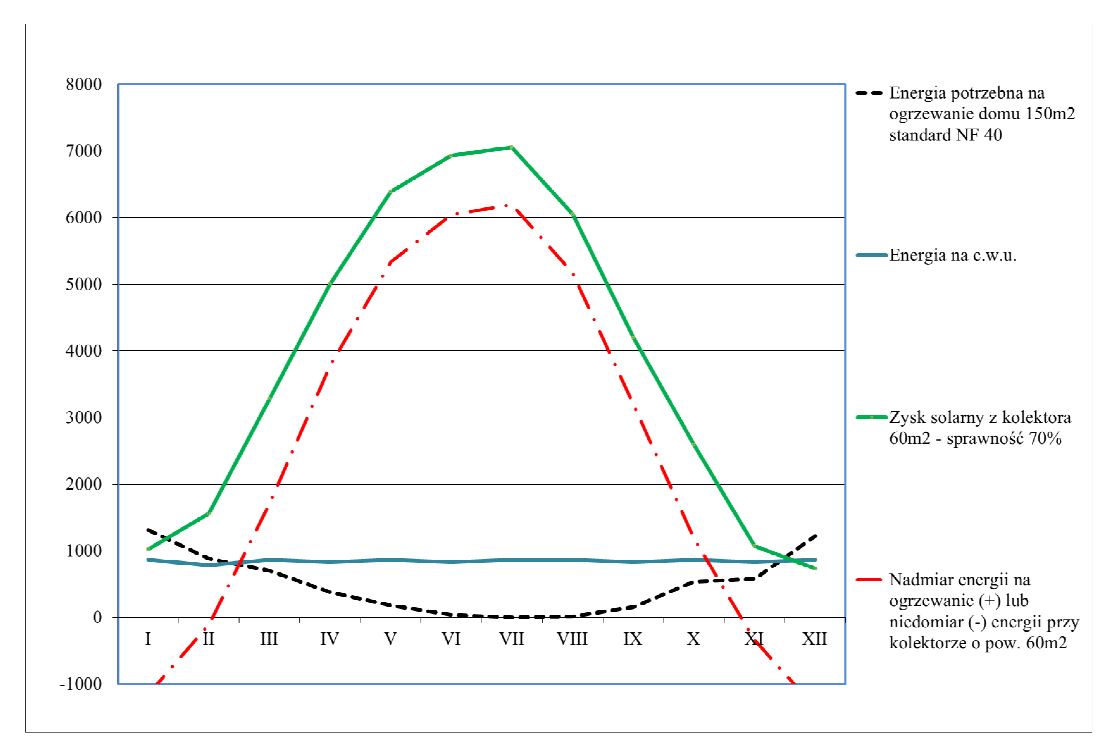

Rys. 3. Bilans energii cieplnej $\mathrm{w}[\mathrm{kWh}] \mathrm{z}$ powietrznych kolektorów słonecznych do ogrzewania i przygotowanie c.w.u. w ciągu roku [8]

Fig. 3. The balance of heat Energy [kWh] from the air solar collectors for heating and preparation of hot tap water during the year [8]

\section{Konwersja energii słonecznej przy pomocy ogniw fotowoltaicznych na energię elektryczną wykorzystywaną w gospodarstwie agroturystycznym}

Według danych z Głównego Urzędu Statystycznego w 2014 roku na obszarze wiejskim 84,2\% wszystkich mieszkań stanowiły domy jednorodzinne, a średnia liczba osób w gospodarstwie domowym wynosiła 3,6. Średnia powierzchnia użytkowa domu jednorodzinnego $\mathrm{w}$ gospodarstwie na wsi posiada $103,7 \mathrm{~m}^{2}$. Na wsi średnie zużycie energii elektrycznej na jedno gospodarstwo domowe wyniosło rocznie $2544 \mathrm{kWh}$ [3]. Założono, że na 10 osób w gospodarstwie agroturystycznym zużycie wynosi $10000 \mathrm{kWh}$ na rok. Możliwe jest zapewnienie zasilania gospodarstwa agroturystycznego $\mathrm{w}$ energię elektryczną przy wykorzystaniu paneli fotowoltaicznych. Bardzo dobrym rozwiązaniem jest montaż dostępnych na rynku gotowych zestawów fotowoltaicznych w systemie on-grid. Energia elektryczna prądu stałego z ogniw fotowoltaicznych przetwarzana jest przez inwerter na energię elektryczną prądu przemiennego o napięciu fazowym $230 \mathrm{~V}$ dostosowanym do domowej instalacji elektrycznej [10,11]. Domowa instalacja elektryczna połączona jest $z$ energetyczną siecią publiczną przez układ sterowania z inwerterem i dwufunkcyjnym licznikiem energii elektrycznej. Licznik ten może zliczać energię elektryczną pobraną z sieci publicznej przez gospodarstwo agroturystyczne lub energię elektryczną przekazywaną z instalacji fotowoltaicznej do sieci publicznej. W tym układzie przy op- 
tymalnych warunkach nasłonecznienia energia elektryczna wytworzona $\mathrm{z}$ ogniw fotowoltaicznych zasila urządzenia elektryczne w gospodarstwie agroturystycznym. Gdy zapotrzebowanie przez gospodarstwo na energię jest niższe niż energia wytwarzana przez ogniwa fotowoltaiczne wówczas nadmiar energii $\mathrm{z}$ instalacji fotowoltaicznej jest przesyłany do publicznej sieci energetycznej. Natomiast gdy energia wytwarzana przez ogniwa fotowoltaiczne nie pokrywa potrzeb gospodarstwa wówczas z publicznej sieci energetycznej pobierana jest energia na wyrównanie potrzeb. Cały proces przekazywania energii elektrycznej do sieci publicznej i pobierania energii z sieci do gospodarstwa jest automatyczny i kontrolowany przez układ sterowania, a dwufunkcyjny licznik energii elektrycznej rejestruje ilości energii przekazanej do sieci publicznej i pobranej z sieci. Dla przykładu zestaw złożony z 38 sztuk modułów ogniw fotowoltaicznych SV60P.4-260 o łącznej powierzchni $64,2 \mathrm{~m}^{2}$ i mocy nominalnej 9,88 kWp współpracujący z inwerterem KACO BLUEPLANET 9.0 TL3 jest w stanie wytworzyć szacunkowo około $9590 \mathrm{kWh} /$ rok energii elektrycznej [12]. $\mathrm{Z}$ analizy wynika, że to rozwiązanie zapewni gospodarstwu agroturystycznemu pokrycie zapotrzebowania na energię elektryczną.

\section{Podsumowanie}

$\mathrm{Z}$ powyższej analizy wynika, że uprawa $3 \times 0,5$ ha wierzby energetycznej zapewnia paliwo na ogrzewanie i przygotowanie c.w.u. w domu energooszczędnym. Poza tym w warunkach klimatycznych Olsztyna możliwe jest wykorzystanie $60 \mathrm{~m}^{2}$ powietrznych kolektorów słonecznych do ogrzewania budynku gospodarstwa agroturystycznego i podgrzewania c.w.u.. Natomiast instalacja ogniw fotowoltaicznych o powierzchni około $64,2 \mathrm{~m}^{2}$ skierowana do strony południowej pokrywa zapotrzebowanie na energię elektryczną gospodarstwa agroturystycznego. W takim budynku wymagane jest odzyskiwanie ciepła $\mathrm{z}$ wentylacji czyli stosowanie rekuperacji. Dopłata do budynku energooszczędnego spełniającego wymagania standard NF 40 wynosi obecnie w Polsce 30000 zł.

Ze względu na specyfikę przyrody i klimatu Warmii i Mazur największe zainteresowanie agroturystyką notuje się w okresie od kwietnia do września. Większe w tym okresie zapotrzebowanie na energię cieplną i elektryczną w gospodarstwie agroturystycznym znakomicie zaspokajają instalacje kolektorów słonecznych i ogniw fotowoltaicznych.

Zatem z powyższej analizy wynika, że przy założonych parametrach w warunkach klimatycznych Olsztyna możliwe jest zapewnienie samowystarczalności energetycznej gospodarstwa agroturystycznego.

\section{Literatura}

[1] Chwieduk D., Energetyka słoneczna budynku, Wydawnictwo Arkady, Warszawa, 2011.

[2] Schlagowski G., Rozwój budownictwa energooszczędnego, pasywnego i zero energetycznego w Europie i w Polsce. Przepisy europejskie i polskie. Polski Instytut Budownictwa Pasywnego Sp. z o.o. Gdańsk 2011. 
[3] Rocznik Głównego Urzędu Statystycznego, 2015.

[4] Fieducik J., Godlewski J., Storing thermal energy from solar collectors for the needs of a detached house, Polish Journal of Environment Studies, vol.23. no.4, 2014.

[5] Stolarski J., Szczukowski S., Tworkowski J., Wierzba energetyczna. Plant Pres, Kraków 2006.

[6] http://www.galileaenergy.com/kolektory-powietrzne-systemy-solar-venti.php, $\quad$ dostęp 23.05.2016 r.\}.

[7] http://www.solarventi.com, \{dostęp 23.05.2016 r.\}.

[8] Fieducik J., Godlewski J., The low energy house using an air solar collector- a case study, Czasopismo techniczne, 3-B(8), 2014, str. 99-105.

[9] GetSolar software Autor: Dipl.-ing Markus Maier. wersja 10.1.1. 21.12.2009 r.

[10] Smolec W., Fototermiczna konwersja energii słonecznej, PWN, Warszawa, 2000.

[11] Lewandowski W. Proekologiczne odnawialne źródła energii, Warszawa, 4, 2012.

[12] www.selfa-pv.com/pl/produkty/moduly-fotowoltaiczne/sv60\{dostęp 23.05.2016 r. \}.

\section{AN ENERGY SELF-SUFFICIENT AGRO TOURISTIC FARM}

\section{S u m m a r y}

The article analyses the energetic needs of a low-energy agro touristic farm. The current parameters of a low-energy house have been presented in detail. In the analysis, the thermal energy needed for heating purposes for duration of a year, hot water for utilities, and necessary electrical energy have been taken into account.

The analysis is based on energy produced in the agro touristic farm, providing energetic selfsufficiency. The demand for thermal energy has been estimated based on the average temperature/days in the particular months of the year, assuming the energy consumption to be $40 \mathrm{kWh} / \mathrm{m} 2 /$ year. To obtain the thermal energy for the farm, the cultivation of energetic willow on a suitable area has been proposed. Alternatively, for heating water an analysis of obtaining it through the use of solar collectors has been provided and the optimal type of collectors chosen.

From this analysis it follows that it is possible to create an energetically self sufficient agro touristic farm in the climatic conditions of Olsztyn.

Keywords: energy self-sufficient farm, willow, photovoltaic cells, solar air collectors

DOI: $10.7862 / \mathrm{rb} .2016 .188$

Przestano do redakcji: $30.06 .2016 r$.

Przyjęto do druku: 30.11.2016 r. 